\title{
Prevalence of Dementia in Japan: A Systematic Review
}

\author{
Hitoshi Okamura ${ }^{a}$ Shinya Ishii ${ }^{c}$ Tomoyuki Ishii $^{d} \quad$ Akira Eboshida $^{b}$ \\ Departments of a Psychosocial Rehabilitation and ${ }^{b}$ Public Health and Health Policy, \\ Institute of Biomedical and Health Sciences, Hiroshima University, Hiroshima, \\ 'Department of Geriatric Medicine, Graduate School of Medicine, University of Tokyo, \\ Tokyo, and dMedical Corporation Tijinkai, Maple Hill Hospital, Otake, Japan
}

\section{Key Words}

Dementia $\cdot$ Prevalence $\cdot$ Systematic review $\cdot$ Japan

\begin{abstract}
Background/Aims: The actual prevalence of dementia in Japan as well as the changes in the prevalence are not well known. Therefore, we undertook a systematic review to collect evidence regarding the prevalence of dementia in Japan. Methods: For this systematic review, we searched 2 electronic databases to identify cross-sectional or repeated cross-sectional studies with data regarding the study population, study location, diagnostic criteria, and prevalence of dementia. Results: Twenty-one studies were selected from 782 references. Sixteen studies surveyed individuals living at home; of these, 5 studies also included hospitalized or institutionalized patients. Most of the studies were conducted using a two-phase survey (phase I: screening, phase II: diagnosis of dementia). The clinical diagnosis of dementia was made based on the guidelines of the Diagnostic and Statistical Manual of Mental Disorders (DSM) in a majority of the studies. The prevalence of all types of dementia ranged from 2.9 to $12.5 \%$ and has been gradually increasing over the past few years. Conclusion: The results of this systematic review suggest that the prevalence of dementia has recently increased. However, further well-designed studies taking into account factors that affect the prevalence of dementia are needed to clarify the actual prevalence.

(C) 2013 S. Karger AG, Basel
\end{abstract}

\section{Introduction}

With the rapid aging of society, the number of people with dementia is likely to increase. The Delphi study [1] indicated that 24.3 million people throughout the world had dementia in 2001. The number of individuals with dementia is expected to increase to 42.3 million by 
2020 and to 81.1 million by 2040 . In Japan, the proportion of elderly individuals aged $\geq 65$ years exceeded $21 \%$ in 2007 , and the country can now be regarded as a super-aging society. Since society in Japan is aging at a faster rate than in other countries and the proportion of elderly individuals is now the highest of any country in the world, the increasing number of patients with dementia has become a serious medical and social problem.

The increasing incidence of dementia is a matter of concern for government authorities, and an accurate estimate of the prevalence of dementia is essential for the effective planning of long-term care and a better understanding of the health service needs of patients with dementia. Recently, Prince et al. [2] conducted a systematic review of the global literature on the prevalence of dementia (1980-2009) and performed a meta-analysis to estimate the prevalence and numbers of those affected aged $\geq 60$ years in 21 regions. They showed that the age-standardized prevalence varied between 5 and $7 \%$ in most world regions, with a higher prevalence in Latin America (8.5\%) and a distinctively lower prevalence in the 4 subSaharan African regions (2-4\%). Although several epidemiological studies on dementia have been conducted in Japan, the resulting reports typically describe single studies not allowing for generalization. Hence, the actual prevalence of dementia and the changes in the prevalence remain unknown. The aim of the present study was to perform a systematic analysis of published epidemiological studies examining the prevalence of dementia in the elderly Japanese population.

\section{Methods}

The literature search was developed and conducted by an experienced systematic reviewer using PubMed and the Ichushi-Web (in Japanese) on March 28, 2012. Studies were eligible for this review if they included the terms 'Dementia', 'Prevalence', or 'Incidence' as well as 'Human' and 'Original article'. Nonresearch articles and studies in which the assessment methods for dementia were not clearly described were excluded. If two or more prevalence estimates for the same region were reported (i.e., use of the same sample on multiple occasions), we used the most recent report in our analysis.

Data extraction for all studies was performed in duplicate by 2 independent reviewers, and the accuracy of the extracted information was confirmed by an additional review. Data were descriptively and qualitatively extracted, and data extraction was completed using an Excel spreadsheet. We noted the first author's name, the journal's name, the study population, study location, and study period. The assessment methods, including the diagnostic criteria, and the major results (prevalence of dementia) were also recorded. After a full text review, if any discrepancies existed between the findings of the 2 reviewers, a third reviewer determined the eligibility of the article and the reviewers were asked to reach a consensus. In addition, the third reviewer also verified that the articles deemed ineligible did not meet the eligibility criteria.

\section{Results}

Of the retrieved 782 citations (609 from PubMed and 173 from the Ichushi-Web), 737 articles not focusing on the general population of Japan were excluded. After we reviewed 45 articles, 24 were excluded as they did not meet our eligibility criteria, and a total of 21 studies (9 in English and 12 in Japanese) [3-23] met the inclusion criteria. The search results are given in figure 1 , and table 1 summarizes the results of the studies that met the inclusion criteria.

Year and Region of Survey

Only 5 of the 21 studies were performed in 2000 or after. Most of the studies were conducted before 2000. Regarding the region surveyed, all studies were performed within a single prefecture, city, town, or village. None of the studies were performed in multiple regions. 


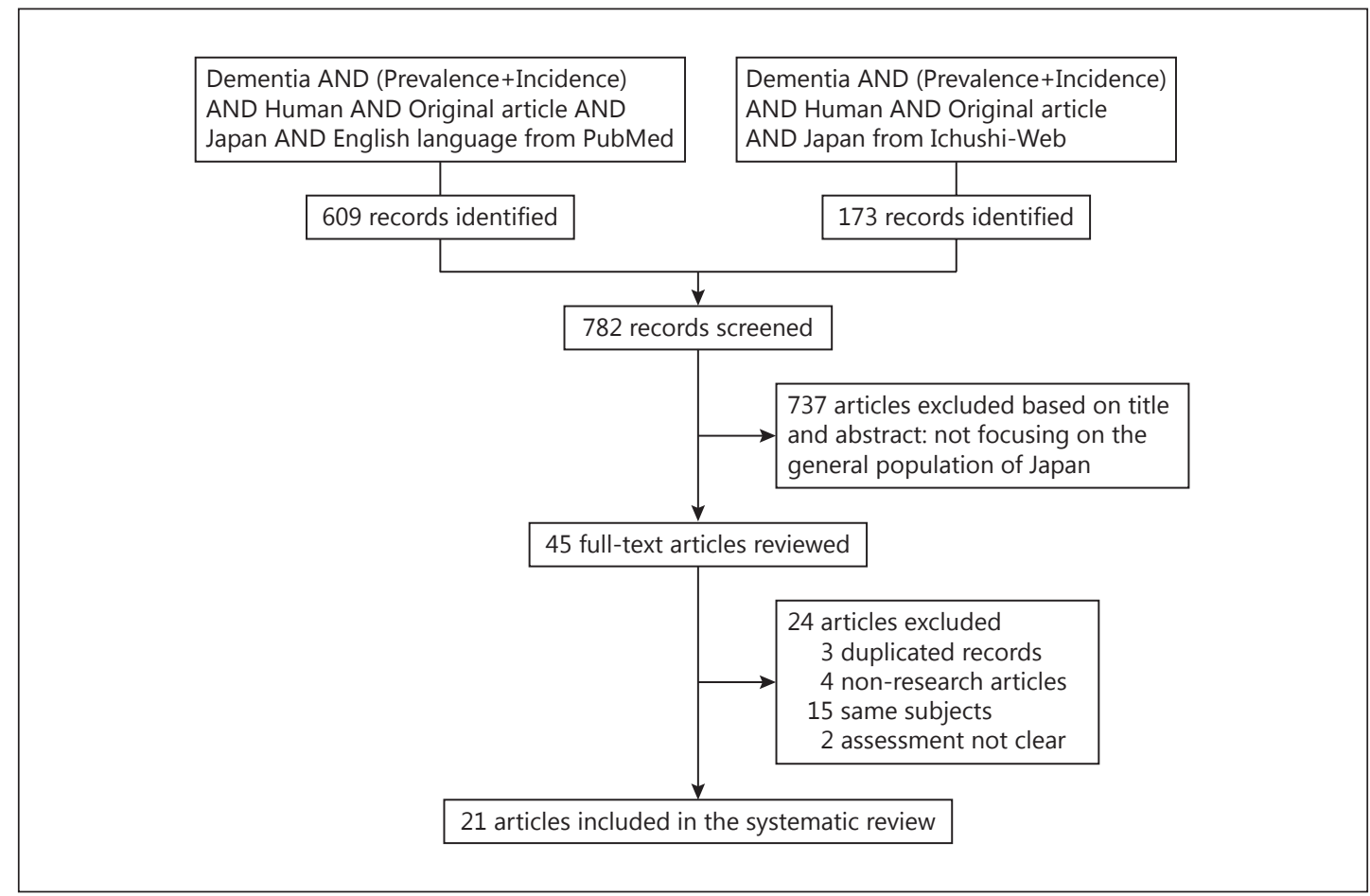

Fig. 1. Identification, screening, and eligibility of subjects.

\section{Subjects}

The subjects surveyed were 65 years or older in most of the studies. Only 2 studies were performed in subjects aged 60 years or older. Most of the studies $(n=16)$ surveyed individuals living at home, of which 5 studies also included hospitalized or institutionalized patients.

\section{Assessment Methods}

With the exception of 2 reports, the studies were conducted using a two-phase survey. Phase I was a screening survey and phase II a survey for the diagnosis of dementia and its subtypes. The screening survey consisted of questionnaires or interviews performed by public health nurses, trained investigators, medical students, or psychiatrists. In phase II, the subjects who were screened in the phase I survey were examined to confirm the presence of dementia. Two studies included not only the subjects in the screened group, but also controls from a non-screened group in the phase II survey. In most of the studies, the clinical diagnosis of dementia was made based on the guidelines of the Diagnostic and Statistical Manual of Mental Disorders, third edition to fourth edition revised (DSM-III, III-R, IV, or IV-R). In 4 studies performed before 1995, the Karasawa senile scale was used to diagnose dementia in the phase II survey.

\section{Prevalence of Dementia}

The prevalence rates for all types of dementia ranged from 2.9 to $12.5 \%$. However, they differ significantly. In 2 repeated cross-sectional studies, the prevalence rates were shown to increase gradually over the years. Furthermore, the latest 2 studies showed that the crude prevalence rate was over $10 \%$. On the other hand, most of the studies in this review did not show age distributions or mean ages, which could have an influence on the prevalence. 
Table 1. Characteristics of studies on the prevalence of dementia in Japan

\begin{tabular}{|c|c|c|c|c|c|}
\hline Reference & $\begin{array}{l}\text { Subjects, } \\
\text { n (\% women) }\end{array}$ & $\begin{array}{l}\text { Region, } \\
\text { urban or rural }\end{array}$ & $\begin{array}{l}\text { Study } \\
\text { period }\end{array}$ & Assessment methods & Major results (prevalence) \\
\hline $\begin{array}{l}\text { Sekita et al. } \\
\text { [3] }\end{array}$ & $\begin{array}{l}\text { Aged } \geq 65 \text { living at home; } \\
1,566(60.9 \%) \text { in } 2005 \\
\text { mean age: } 75.9 \pm 7.4 ; \\
1,437(60.3 \%) \text { in } 1998 \\
\text { mean age: } 74.8 \pm 7.2 ; \\
1,189(60.1 \%) \text { in } 1992 \\
\text { mean age: } 74.2 \pm 6.9 \\
887(60.2 \%) \text { in } 1985 \\
\text { mean age: } 73.7 \pm 6.4\end{array}$ & $\begin{array}{l}\text { Hisayama } \\
\text { (Fukuoka), rural }\end{array}$ & $\begin{array}{l}2005, \\
1998, \\
1992, \text { and } \\
1985\end{array}$ & $\begin{array}{l}\text { Phase I: HDS, HDS-R, and MMSE by } \\
\text { trained psychologists; } \\
\text { phase II: DSM-III and DSM-III-R } \\
\text { (+Karasawa's criteria and Hachinski's } \\
\text { scale) to subjects in the screened } \\
\text { group }\end{array}$ & $\begin{array}{l}\text { Crude prevalence: } \\
\text { 2005: 12.5\% (AD 6.1\%, VD } \\
\text { 3.3\%, other 3.1\%), } \\
\text { 1998: 7.1\% (AD 3.4\%, VD } \\
\text { 1.7\%, other 1.9\%), } \\
\text { 1992: 5.7\% (AD 1.8\%, VD } \\
\text { 1.9\%, other 2.1\%), } \\
\text { 1985: 6.7\% (AD 1.4\%, VD } \\
\text { 2.4\%, other 2.9\%); } \\
\text { Age- and sex-adjusted } \\
\text { prevalence: } \\
\text { 2005: 8.3\% (AD 3.8\%, VD } \\
\text { 2.5\%, other 2.0\%), } \\
\text { 1998: 5.3\% (AD 2.3\%, VD } \\
\text { 1.5\%, other 1.5\%), } \\
\text { 1992: 4.4\% (AD 1.3\%, VD } \\
\text { 1.5\%, other 1.7\%), } \\
\text { 1985: 6.0\% (AD 1.1\%, VD } \\
\text { 2.3\%, other } 2.6 \% \text { ) }\end{array}$ \\
\hline $\begin{array}{l}\text { Wada-Isoe et al. } \\
\text { [4] }\end{array}$ & $\begin{array}{l}\text { Aged } \geq 65 \text { living at home } \\
\text { or in nursing homes; } \\
943(59.1 \%) \\
\text { mean age; ND }\end{array}$ & $\begin{array}{l}\text { Ama-cho } \\
\text { (Tottori), rural }\end{array}$ & $\begin{array}{l}\text { March } \\
2008\end{array}$ & $\begin{array}{l}\text { Phase I: interview by public health } \\
\text { nurses; } \\
\text { phase II: DSM-IV-R (+NINCDS-ADRDA } \\
\text { and NINDS-AIREN) to subjects in the } \\
\text { screened group }\end{array}$ & $\begin{array}{l}11.3 \%(104 / 917)(A D 7.2 \% \text {, } \\
\text { VD } 1.7 \% \text {, other } 2.4 \%)\end{array}$ \\
\hline $\begin{array}{l}\text { Wakutani et al. } \\
\text { [5] }\end{array}$ & $\begin{array}{l}\text { Aged } \geq 65 \text { living at home; } \\
1,823(N D) \text { in } 2000 ; \\
1,626(N D) \text { in } 1990 ; \\
1,236(N D) \text { in } 1980 ; \\
\text { mean age: ND }\end{array}$ & $\begin{array}{l}\text { Daisen-cho } \\
\text { (Tottori), rural }\end{array}$ & $\begin{array}{l}2000, \\
1990, \text { and } \\
1980\end{array}$ & $\begin{array}{l}\text { Phase I: questionnaire; } \\
\text { phase II: DSM-III and DSM-III-R }\end{array}$ & $\begin{array}{l}\text { 2000: } 7.4 \% \\
\text { 1990: } 4.9 \% \\
\text { 1980: } 4.4 \%\end{array}$ \\
\hline $\begin{array}{l}\text { Nakamura et al. } \\
{[6]}\end{array}$ & $\begin{array}{l}\text { Aged } \geq 65 \text { living at home; } \\
7,847(58.9 \%) \\
\text { mean age: ND }\end{array}$ & $\begin{array}{l}\text { Itoigawa } \\
\text { (Niigata), rural }\end{array}$ & $\begin{array}{l}\text { December } \\
1997 \text { to } \\
\text { February } \\
1999\end{array}$ & $\begin{array}{l}\text { Phase I: questionnaire by public } \\
\text { health nurses; } \\
\text { phase II: DSM-IV to subjects in the } \\
\text { screened group and controls from the } \\
\text { non-screened group }\end{array}$ & $\begin{array}{l}\text { Dementia: } 6.2 \% \\
\text { CDR 0.5: } 4.4 \%\end{array}$ \\
\hline $\begin{array}{l}\text { Suzuki et al. } \\
\text { [7] } \\
\text { (in Japanese) }\end{array}$ & $\begin{array}{l}\text { Aged } \geq 65 \text { living at home, } \\
\text { in hospital, or in nursing } \\
\text { homes; } 2,046(58.0 \%) \text {, } \\
\text { mean age: ND }\end{array}$ & $\begin{array}{l}\text { Toyama } \\
\text { Prefecture, urban } \\
\text { and rural }\end{array}$ & 2001 & $\begin{array}{l}\text { Phase I: interview and HDS-R by } \\
\text { trained interviewers; } \\
\text { phase II: ICD-10 (+Hachinski's scale, } \\
\text { HDS-R, and MMSE) to subjects in the } \\
\text { screened group }\end{array}$ & $\begin{array}{l}8.8 \% \text { (AD } 4.4 \% \text {, VD } 2.8 \% \text { ) } \\
7.2 \% \text { in } 1996 \\
5.7 \% \text { in } 1990 \\
4.7 \% \text { in } 1985\end{array}$ \\
\hline $\begin{array}{l}\text { Ikeda et al. } \\
\text { [8] }\end{array}$ & $\begin{array}{l}\text { Aged } \geq 65 \text { living at home; } \\
1,162(\mathrm{ND}) \\
\text { mean age: } \mathrm{ND}\end{array}$ & $\begin{array}{l}\text { Nakayama } \\
\text { (Ehime), rural }\end{array}$ & $\begin{array}{l}\text { January } \\
1997 \text { to } \\
\text { March } \\
1998\end{array}$ & $\begin{array}{l}\text { Phase I: MMSE, SMQ, and Karasawa } \\
\text { screening test by psychiatrists and } \\
\text { public health nurses; } \\
\text { phase II: clinical examination } \\
\text { (including NPI and CDR); } \\
\text { phase III: DSM-III-R and DSM-IV (+CT } \\
\text { and NINCDS-ADRDA) to subjects in } \\
\text { the screened group }\end{array}$ & $\begin{array}{l}5.2 \%(60 / 1,162)(A D 1.8 \% \text {, } \\
\text { VD } 2.4 \% \text {, other } 1.0 \%)\end{array}$ \\
\hline $\begin{array}{l}\text { Yamada et al. } \\
\text { [9] }\end{array}$ & $\begin{array}{l}\text { Aged } \geq 65 \text { living at home; } \\
3,715(59.5 \%) \\
\text { mean age: ND }\end{array}$ & $\begin{array}{l}\text { Amino-cho } \\
\text { (Kyoto), rural }\end{array}$ & $\begin{array}{l}\text { January } \\
1998\end{array}$ & $\begin{array}{l}\text { Phase I: interview by public health } \\
\text { nurses; } \\
\text { phase II: DSM-III-R (+MMSE, MRI, } \\
\text { NINCDS-ADRDA, and NINDS-AIREN) } \\
\text { to subjects in the screened group }\end{array}$ & $\begin{array}{l}3.8 \%(142 / 3,715)(A D 2.1 \% \text {, } \\
\text { VD } 1.0 \% \text {, other } 0.7 \%)\end{array}$ \\
\hline $\begin{array}{l}\text { Shiba et al. } \\
{[10]}\end{array}$ & $\begin{array}{l}\text { Aged } \geq 65 \text { living at home; } \\
201(N D) \\
\text { mean age: ND }\end{array}$ & $\begin{array}{l}\text { Hanazono-mura } \\
\text { (Wakayama), } \\
\text { rural }\end{array}$ & $\begin{array}{l}\text { January } \\
1995\end{array}$ & $\begin{array}{l}\text { Phase I: HDS-R by physicians; } \\
\text { phase II: DSM-III-R (+NINCDS- } \\
\text { ADRDA and Hachinski's scale) to } \\
\text { subjects in the screened group }\end{array}$ & $\begin{array}{l}8.5 \%(17 / 201)(\mathrm{AD} 3.5 \%, \mathrm{VD} \\
3.0 \% \text {, other } 2.0 \%)\end{array}$ \\
\hline $\begin{array}{l}\text { Urakami et al. } \\
{[11]}\end{array}$ & $\begin{array}{l}\text { Aged } \geq 60 \text { living at home; } \\
2,203(N D) \text { in } 1990, \\
1,730 \text { (ND) in } 1980, \\
\text { mean age: ND }\end{array}$ & $\begin{array}{l}\text { Daisen-cho } \\
\text { (Tottori), rural }\end{array}$ & $\begin{array}{l}1990 \text { and } \\
1980\end{array}$ & $\begin{array}{l}\text { Phase I: questionnaire by health } \\
\text { officers; } \\
\text { phase II: DSM-III (+NINCDS-ADRDA } \\
\text { and Hachinski's scale) to subjects in } \\
\text { the screened group }\end{array}$ & $\begin{array}{l}\text { 1990: } 3.7 \%(82 / 2,203)(A D \\
1.9 \% \text {, VD } 1.4 \% \text {, other } 0.4 \%) \\
1980: 3.2 \%(56 / 1,730)(A D \\
1.4 \% \text {, VD } 1.5 \% \text {, other } 0.3 \%)\end{array}$ \\
\hline
\end{tabular}


Table 1 (continued)

\begin{tabular}{|c|c|c|c|c|c|}
\hline Reference & $\begin{array}{l}\text { Subjects, } \\
\text { n (\% women) }\end{array}$ & $\begin{array}{l}\text { Region, } \\
\text { urban or rural }\end{array}$ & $\begin{array}{l}\text { Study } \\
\text { period }\end{array}$ & Assessment methods & Major results (prevalence) \\
\hline $\begin{array}{l}\text { Nakajima et al. } \\
{[12]} \\
\text { (in Japanese) }\end{array}$ & $\begin{array}{l}\text { Aged } \geq 65 \text { living at home; } \\
3,132(\mathrm{ND}) \\
\text { mean age: } \mathrm{ND}\end{array}$ & $\begin{array}{l}\text { K-cho (Kyoto), } \\
\text { rural }\end{array}$ & $\begin{array}{l}\text { March } \\
1994 \text { to } \\
\text { August } \\
1995\end{array}$ & $\begin{array}{l}\text { Phase I: questionnaire; } \\
\text { phase II: DSM-III-R (+NINCDS- } \\
\text { ADRDA and Hachinski's scale) to } \\
\text { subjects in the screened group }\end{array}$ & $4.8 \%$ \\
\hline $\begin{array}{l}\text { Ogura et al. } \\
{[13]}\end{array}$ & $\begin{array}{l}\text { Aged } \geq 65 \text { living at home, } \\
\text { in hospital, or in nursing } \\
\text { homes; } \\
3,312(63.1 \%) \\
\text { mean age: ND }\end{array}$ & $\begin{array}{l}\text { Hirara City, } \\
\text { Gusukube Town, } \\
\text { Yanaguni Town, } \\
\text { Yonabaru Town } \\
\text { (Okinawa), urban } \\
(61.1 \%) \text { and } \\
\text { rural }(38.9 \%)\end{array}$ & $\begin{array}{l}\text { August } \\
1991 \text { to } \\
\text { January } \\
1992\end{array}$ & $\begin{array}{l}\text { Phase I: NIMH DIS and MMSE by } \\
\text { students; } \\
\text { phase II: DSM-III-R (+NINCDS- } \\
\text { ADRDA and Hachinski's scale) to } \\
\text { subjects in the screened group }\end{array}$ & $\begin{array}{l}\text { Estimated prevalence: } 6.7 \% \\
(\mathrm{AD}, \mathrm{VD} \text {, and other }=46.5, \\
30.8 \text {, and } 22.7 \% \text {, } \\
\text { respectively) }\end{array}$ \\
\hline $\begin{array}{l}\text { Imai et al. } \\
\text { [14] } \\
\text { (in Japanese) }\end{array}$ & $\begin{array}{l}\text { Aged } \geq 65 \text { living at home; } \\
4,259(58.4 \%) \\
\text { mean age: ND }\end{array}$ & $\begin{array}{l}\text { Kanagawa } \\
\text { Prefecture } \\
\text { (excluding } \\
\text { Kawasaki and } \\
\text { Yokohama), } \\
\text { urban and rural }\end{array}$ & $\begin{array}{l}\text { June } \\
1992 \text { to } \\
\text { November } \\
1992\end{array}$ & $\begin{array}{l}\text { Phase I: interview by trained } \\
\text { interviewers; } \\
\text { phase II: DSM-III-R (+NINCDS- } \\
\text { ARDRA, GDS, HDS-R, NM scale, and } \\
\text { CT) to subjects in the screened group } \\
\text { and controls from the non-screened } \\
\text { group }\end{array}$ & $4.8 \%$ (AD 1.8\%, VD 1.8\%) \\
\hline $\begin{array}{l}\text { Miyanaga et al. } \\
\text { [15] } \\
\text { (in Japanese) }\end{array}$ & $\begin{array}{l}\text { Aged } \geq 60 \text { living at home, } \\
\text { in hospital, or in nursing } \\
\text { homes; } \\
3,827(56.7 \%) \text { in } 1991, \\
3,485(57.1 \%) \text { in } 1989, \\
\text { mean age: ND }\end{array}$ & $\begin{array}{l}\text { Yamato-cho } \\
\text { (Gunma), rural }\end{array}$ & $\begin{array}{l}\text { June } 1989 \\
\text { to May } \\
1990 \text {, and } \\
\text { June } 1991 \\
\text { to August } \\
1991\end{array}$ & Interview and Karasawa senile scale & $\begin{array}{l}\text { 1991: } 6.2 \%(8.2 \% \text { in aged } \\
\geq 65) \\
\text { 1989: } 5.9 \%(7.9 \% \text { in aged } \\
\geq 65)\end{array}$ \\
\hline $\begin{array}{l}\text { Sugasaki et al. } \\
\text { [16] } \\
\text { (in Japanese) }\end{array}$ & $\begin{array}{l}\text { Aged } \geq 65 \text { living at home; } \\
491 \text { (ND), } \\
\text { mean age: ND }\end{array}$ & $\begin{array}{l}\text { Nagasaki } \\
\text { Prefecture, urban } \\
\text { and rural }\end{array}$ & $\begin{array}{l}1989 \text { to } \\
1990\end{array}$ & $\begin{array}{l}\text { Phase I: interview by welfare } \\
\text { commissioners; } \\
\text { phase II: DSM-III-R to subjects in the } \\
\text { screened group }\end{array}$ & $\begin{array}{l}4.3 \% \text { (isolated island } 8.3 \% \text {, } \\
\text { mainland } 3.0 \% \text { ) }\end{array}$ \\
\hline $\begin{array}{l}\text { Sugasaki et al. } \\
\text { [17] } \\
\text { (in Japanese) }\end{array}$ & $\begin{array}{l}\text { Aged } \geq 65 \text { living at home; } \\
1,454(53.9 \%) \\
\text { mean age: } N D\end{array}$ & $\begin{array}{l}\text { Nagasaki City, } \\
\text { urban }\end{array}$ & $\begin{array}{l}\text { November } \\
1989 \text { to } \\
\text { December } \\
1990\end{array}$ & $\begin{array}{l}\text { Phase I: questionnaire; } \\
\text { phase II: DSM-III-R to subjects in the } \\
\text { screened group }\end{array}$ & $\begin{array}{l}2.9 \%(\mathrm{AD}, \mathrm{VD}, \text { and other }= \\
48.4,44.8 \text {, and } 6.8 \%, \\
\text { respectively) }\end{array}$ \\
\hline $\begin{array}{l}\text { Kumagai et al. } \\
\text { [18] } \\
\text { (in Japanese) }\end{array}$ & $\begin{array}{l}\text { Aged } \geq 65 \text { living at home; } \\
1,004(60.3 \%) \\
\text { mean age: } N D\end{array}$ & $\begin{array}{l}\text { Shibata City } \\
\text { (Niigata), rural }\end{array}$ & $\begin{array}{l}\text { June } 1988 \\
\text { to July } \\
1988\end{array}$ & $\begin{array}{l}\text { Phase I: interview by public health } \\
\text { nurses; } \\
\text { phase II: Karasawa senile scale to } \\
\text { subjects in the screened group }\end{array}$ & $4.8 \%$ \\
\hline $\begin{array}{l}\text { Muto et al. } \\
\text { [19] } \\
\text { (in Japanese) }\end{array}$ & $\begin{array}{l}\text { Aged } \geq 65 \text { living at home, } \\
\text { in hospital, or in nursing } \\
\text { homes; } 1,923(56.4 \%) \text {, } \\
\text { mean age: ND }\end{array}$ & $\begin{array}{l}\text { Nagano } \\
\text { Prefecture, urban } \\
\text { and rural }\end{array}$ & $\begin{array}{l}\text { July } 1987 \\
\text { to January } \\
1988\end{array}$ & $\begin{array}{l}\text { Phase I: questionnaire; } \\
\text { phase II: DSM-III to subjects in the } \\
\text { screened group }\end{array}$ & $6.4 \%$ \\
\hline $\begin{array}{l}\text { Fukunishi et al. } \\
\text { [20] } \\
\text { (in Japanese) }\end{array}$ & $\begin{array}{l}\text { Aged } \geq 65 \text { living at home; } \\
3,797(58.2 \%) \text { in } 1988 \\
3,754(58.2 \%) \text { in } 1987 \\
\text { mean age: } N D\end{array}$ & $\begin{array}{l}\text { Miki-cho } \\
\text { (Kagawa), urban } \\
\text { and rural }\end{array}$ & $\begin{array}{l}\text { June } 1987 \\
\text { and June } \\
1986\end{array}$ & $\begin{array}{l}\text { First screening: questionnaire and } \\
\text { interview by town workers; second } \\
\text { evaluation: DSM-III, DSM-III-R to } \\
\text { subjects in the screened group }\end{array}$ & $\begin{array}{l}4.1 \% \text { in } 1988(\mathrm{AD} / \mathrm{VD}=1.00) \\
4.1 \% \text { in } 1987(\mathrm{AD} / \mathrm{VD}=0.98)\end{array}$ \\
\hline $\begin{array}{l}\text { Nishimatsu et } \\
\text { al. [21] } \\
\text { (in Japanese) }\end{array}$ & $\begin{array}{l}\text { Aged } \geq 65 \text { living at home; } \\
1,218(57.6 \%) \\
\text { mean age: } N D\end{array}$ & $\begin{array}{l}\text { Ohmishima-cho, } \\
\text { Hirota-mura, and } \\
\text { Shigenobu-cho } \\
\text { (Ehime), rural }\end{array}$ & $\begin{array}{l}\text { September } \\
1985 \text { to } \\
\text { July } 1986\end{array}$ & HDS, Karasawa senile scale & $4.3 \%(37 / 858)$ \\
\hline $\begin{array}{l}\text { Fujikawa et al. } \\
\text { [22] } \\
\text { (in Japanese) }\end{array}$ & $\begin{array}{l}\text { Aged } \geq 65 \text { living at home; } \\
849(64.4 \%) \\
\text { mean age: ND }\end{array}$ & $\begin{array}{l}\text { Hoshini-mura } \\
\text { (Fukuoka), rural }\end{array}$ & $\begin{array}{l}\text { July } 1983 \\
\text { to } \\
\text { August } \\
1983\end{array}$ & $\begin{array}{l}\text { Phase I: interview by public health } \\
\text { nurses; } \\
\text { phase II: Karasawa senile scale to } \\
\text { subjects in the screened group }\end{array}$ & $6.6 \%$ \\
\hline $\begin{array}{l}\text { Shibayama et } \\
\text { al. [23] }\end{array}$ & $\begin{array}{l}\text { Aged } \geq 65 \text { living at home; } \\
3,106(\mathrm{ND}) \\
\text { mean age: } \mathrm{ND}\end{array}$ & $\begin{array}{l}\text { Aichi (Nagoya } \\
\text { City: 986), urban } \\
\text { and rural }\end{array}$ & $\begin{array}{l}\text { October } \\
1982 \text { to } \\
\text { August } \\
1983\end{array}$ & $\begin{array}{l}\text { Phase I: interview by trained } \\
\text { interviewers; } \\
\text { phase II: DSM-III, ICD- } 9 \text { (+Hachinski's } \\
\text { scale) to subjects in the screened } \\
\text { group }\end{array}$ & $\begin{array}{l}5.8 \%(181 / 3,106)(\text { AD } 2.4 \% \text {, } \\
\text { VD } 2.8 \% \text {, other } 0.6 \%)\end{array}$ \\
\hline
\end{tabular}


Okamura et al.: Prevalence of Dementia in Japan: A Systematic Review

\section{Discussion}

The present systematic review shows that the prevalence of all causes of dementia in the general population of elderly Japanese individuals has increased in the last few years. One reason for this increase may be the aging of the study population since age is one of the strongest risk factors for dementia. However, as most of the studies did not show age distributions or mean ages, we could not carry out a meta-analysis or an age-stratified analysis and clarify the influence of age on the prevalence. Therefore, the fact that populations are aging more than previously has a possible influence on the prevalence of dementia, but more welldesigned studies are needed. Other possible causes may be the recent increase in the prevalence of metabolic disorders, such as hypercholesterolemia and glucose intolerance, which are known to be associated with the risk of dementia [24-26], or the decline in the mortality rate because of substantial care for patients with dementia.

On the other hand, the prevalence rates differed from one survey to another. The variation in the prevalence rates was likely due to several factors. First, the study designs differed somewhat. In most of the studies, the phase II survey was conducted only in individuals who were screened and suspected of having dementia during the phase I survey. The phase I screening methods consisted of various methods such as personal interviews, indirect interviews, or questionnaires, and various examiners, such as nurses, physicians, or students, conducted the survey. Therefore, the prevalence rates may be underestimated because of the failure to take into account subjects with dementia who were not suspected of having dementia during the phase I survey. Only 2 studies included subjects in the phase II survey who had been randomly selected from a non-screened group.

Second, many studies surveyed individuals living at home, and some studies included hospitalized or institutionalized patients as well. The prevalence of dementia is likely to be higher among subjects who are hospitalized or in an institution for the elderly than among those who live at home. Therefore, whether hospitalized and institutionalized persons are included in the survey may have a major impact on the prevalence of dementia found.

Third, the age structure of the population is an important factor in estimating the prevalence. Generally, the prevalence of dementia increases remarkably with increasing age. Therefore, the age distribution must be considered when comparing the prevalence of dementia in different populations of subjects aged 65 years or older. In this review, the age structure could not be assessed because the age distribution was not always described.

Finally, the prevalence of dementia differs between rural and urban areas [27]. The prevalence in a rural area was reported to be higher than that in an urban area [28]. Rural communities may be more accepting and tolerant of elderly persons with dementia than urban communities. Furthermore, the family structure in rural areas differs from that in urban areas. In rural areas, elderly individuals often live in larger family units and are supported by them [23]. These situations and circumstances might delay hospitalization and institutionalization and might result in a higher prevalence of dementia in community-dwelling elderly individuals. All studies included in this review were conducted within a single prefecture, city, town, or village, and none of the reports compared the prevalence of dementia between rural and urban areas.

Differences in the diagnostic criteria used to diagnose dementia are also likely a source of variation in the prevalence of dementia among the reports. Most of the studies included in the present review used the DSM criteria to diagnose dementia, and a few studies used CT or MRI examinations as complimentary diagnostic procedures. Regarding the diagnosis of dementia, Snowden et al. [29] examined the clinical diagnostic accuracy of dementia; they showed a high correspondence between clinical and pathological diagnoses and suggested that with the clinical diagnosis, it is possible to distinguish different forms of dementia on 
Okamura et al.: Prevalence of Dementia in Japan: A Systematic Review

clinical grounds with a high degree of accuracy. However, there is need to study whether the DSM criteria are better assessment methods for dementia than other clinical assessments or measurement scales.

\section{Conclusion}

The results of this systematic review suggest that the prevalence of dementia has recently increased. However, a critical investigation of the study design (survey method), method of selecting subjects, diagnostic criteria, and the age structure of the population as well as a comparison between rural and urban areas is unlikely to be sufficient. To clarify the actual conditions of dementia in Japan, further research conducted in multiple regions, taking into account the above-mentioned factors that affect the prevalence of dementia, and the development of a database are needed.

\section{Disclosure Statement}

The authors have no potential conflicts of interest to declare.

\section{References}

1 Ferri CP, Prince M, Brayne C, Brodaty H, Fratiglioni L, Ganguli M, et al: Global prevalence of dementia: a Delphi consensus study. Lancet 2005;366:2112-2117.

2 Prince M, Bryce R, Albanese E, Wimo A, Ribeiro W, Ferri CP: The global prevalence of dementia: a systematic review and metaanalysis. Alzheimers Dement 2013;9:63-75.

3 Sekita A, Ninomiya T, Tanizaki Y, Doi Y, Hata J, Yonemoto K, et al: Trends in prevalence of Alzheimer's disease and vascular dementia in a Japanese community: the Hisayama Study. Acta Psychiatr Scand 2010;122:319325.

4 Wada-Isoe K, Uemura Y, Suto Y, Doi K, Imamura K, Hayashi A, et al: Prevalence of dementia in the rural island town of Ama-cho, Japan. Neuroepidemiology 2009;32:101-106.

- 5 Wakutani Y, Kusumi M, Wada K, Kawashima M, Ishizaki K, Mori M, et al: Longitudinal changes in the prevalence of dementia in a Japanese rural area. Psychogeriatrics 2007; 7:150-154.

6 Nakamura S, Shigeta M, Iwamoto M, Tsuno N, Niina R, Homma A, Kawamuro Y: Prevalence and predominance of Alzheimer type dementia in rural Japan. Psychogeriatrics 2003;3:97-103.

7 Suzuki M, Fukuda T, Naruse Y, Kazukawa S, Handa K, Ishikawa H: Changes in the prevalence of dementia drawn from the epidemiological surveys in Toyama prefecture (in Japanese). Jpn J Geriatr Psychiatry 2003; 14:1509-1518.

8 Ikeda M, Hokoishi K, Maki N, Nebu A, Tachibana N, Komori K, et al: Increased prevalence of vascular dementia in Japan: a community-based epidemiological study. Neurology 2001;57:839-844.

- 9 Yamada T, Hattori H, Miura A, Tanabe M, Yamori Y: Prevalence of Alzheimer's disease, vascular dementia and dementia with Lewy bodies in a Japanese population. Psychiatry Clin Neurosci 2001;55:21-25.

10 Shiba M, Shimogaito J, Kose A, Fujiuchi S, Nishiyama H, Yoshimasu F, et al: Prevalence of dementia in the rural village of Hanazono-mura, Japan. Neuroepidemiology 1999;18:32-36.

-11 Urakami K, Adachi Y, Wakutani Y, Isoe K, Ji Y, Takahashi K, Nakashima K: Epidemiologic and genetic studies of dementia of the Alzheimer type in Japan. Dement Geriatr Cogn Disord 1998;9:294-298.

12 Nakajima K, Ueda Y, Kono I, Tanaka N, Mizuno T, Makino M, et al: Prevalence of dementia and its subtypes in a rural area in Japan (in Japanese). Jpn J Geriatr 1998;35:530-534.

13 Ogura C, Nakamoto H, Uema T, Yamamoto K, Yonemori T, Yoshimura T: Prevalence of senile dementia in Okinawa, Japan. COSEPO Group. Study Group of Epidemiology for Psychiatry in Okinawa. Int J Epidemiol 1995; 24:373-380

14 Imai Y, Homma A, Hasegawa K, Hirakawa Y, Kosaka A, Oikawa K, Shimogaki H: An epidemiological study on dementia in Kanagawa prefecture (in Japanese). Jpn J Geriatr Psychiatry 1994;5:855-862.

15 Miyanaga K, Yonemura K, Kuroiwa T, Saito Y, Mori H, Gondaira T: An epidemiological study on dementia in Yamato town - prevalence, incidence and mortality (in Japanese). Jpn J Geriatr Psychiatry 1994;5:323-332.

16 Sugasaki H, Ohta Y, Yoshitake K, Fujita C, Hamada Y, Matsunaga F, Kawasaki N: A socio-psychiatric study of senile dementia at home in Nagasaki prefecture (in Japanese). Jpn J Soc Psychiatry 1992;15:101-107. 
17 Sugasaki H, Ohta Y, Michitsuji S, Fujita C, Yoshitake K, Kawaguchi S, et al: A socio-psychiatric study of senile dementia at home in Nagasaki city (in Japanese). Kyushu N-psych 1992;38:188-198.

18 Kumagai K, Suga R, Oguma T, Naito H, Koizumi T: Epidemiological survey on major depression and dementia among the old at home in Kawahigashi region: prevalence rates and one year outcome (in Japanese). Jpn J Clin Psychiatry 1992;21:1483-1490.

19 Muto T, Toru M, Ogata H, Tatsumi N, Shoda S, Yamamoto T, et al: Epidemiological investigation of demented aged in Nagano Prefecture (in Japanese). Seishin Shinkeigaku Zasshi 1990;92:224-241.

20 Fukunishi I, Hayabara T, Morioka E, Izumi H, Hosokawa K: Epidemiological investigation of senile dementia at home - with special reference to incidence and prevalence rate in Miki-cho, Kagawa Prefecture (in Japanese). Seishin Shinkeigaku Zasshi 1989;91:401-428.

21 Nishimatsu O, Horiguchi J, Yamiya Y, Onishi K, Hirota S, Matsuda K, et al: A survey of the elderly in three provinces of Ehime prefecture and home care problems of patient with senile dementia (in Japanese). Jpn J Clin Psychiatry 1988;17:1669-1678.

22 Fujikawa N, Itonaga Y, Arikawa K, Nakamura M, Fukuhara T: Prevalence of dementia in old ages in the rural area (in Japanese). Jpn J Clin Psychiatry 1986;15:229-241.

23 Shibayama H, Kasahara Y, Kobayashi H: Prevalence of dementia in a Japanese elderly population. Acta Psychiatr Scand 1986;74:144-151.

24 Abellan van Kan G, Rolland Y, Nourhashémi F, Coley N, Andrieu S, Vellas B: Cardiovascular disease risk factors and progression of Alzheimer's disease. Dement Geriatr Cogn Disord 2009;27:240-246.

25 Arvanitakis Z, Wilson RS, Bienias JL, Evans DA, Bennett DA: Diabetes mellitus and risk of Alzheimer disease and decline in cognitive function. Arch Neurol 2004;61:661-666.

-26 Kivipelto M, Helkala EL, Laakso MP, Hänninen T, Hallikainen M, Alhainen K, et al: Midlife vascular risk factors and Alzheimer's disease in later life: longitudinal, population based study. BMJ 2001;322:1447-1451.

-27 Keefover RW, Rankin ED, Keyl PM, Wells JC, Martin J, Shaw J: Dementing illnesses in rural populations: the need for research and challenges confronting investigators. J Rural Health 1996;12:178-187.

28 Rajkumer S, Kumar S, Thara R: Prevalence of dementia in a rural setting: a report from India. Int J Geriatr Psychiatry 1997;12:702-707.

29 Snowden JS, Thompson JC, Stopford CL, Richardson AMT, Gerhard A, Neary D, et al: The clinical diagnosis of early-onset dementias: diagnostic accuracy and clinicopathological relationships. Brain 2011;134:24782492. 